\title{
EVALUATION OF DIRECT SEEDING AND SEEDLING PLANTING OF TWO NEOTROPICAL TREE SPECIES WITH THE USE OF NATURAL INPUTS ${ }^{1}$
}

\author{
Alexandre Hüller ${ }^{2}$, Geraldo Ceni Coelho ${ }^{3 *}$, Géri Eduardo Meneghello ${ }^{4}$ and Silmar Teichert Peske ${ }^{4}$
}

\author{
${ }^{1}$ Received on 12.10.2012 accepted for publication on 26.06.2017. \\ ${ }^{2}$ Universidade Federal de Pelotas, Brasil. E-mail: <alexandre.huller@hotmail.com>. \\ ${ }^{3}$ Universidade Federal da Fronteira Sul, Campus Chapecó, Brasil. E-mail: <cenicoelho@gmail.com>. \\ ${ }^{4}$ Universidade Federal de Pelotas, Pós-Graduação em Ciência e Tecnologia de Sementes, Rio Grande do Sul, Brasil. E-mail: \\ <gmeneghello@gmail.com>and <peske@ufpel.tche.br>. \\ *Corresponding author.
}

\begin{abstract}
Direct seeding of native tree species could be a low cost alternative for forest restoration. The paper aimed at evaluate direct seeding of two species from Southern Brazil, Schinus terebinthifolius Raddi and Citharexylum solanaceum Chamisso, comparing with seedling planting. The effects and costs of forest topsoil and forest litter addition were also evaluated in the direct seeding. The experiment was accomplished during 2009/2010. The treatments of direct seeding were CONTROL - control without seeding, TSEED - only seeding, TLITTER-seeding with forest litter cover, TTOPSOIL - seeding with forest topsoil, TBOTH - seeding with forest litter and with forest topsoil, LTCONTROL - control with forest litter and forest topsoil. The species $C$. solanaceum did not germinate at field. The species $S$. terebinthifolius had higher germination in the TBOTH, either at 30 days $(21.6 \%)$ and 360 days $(9.0 \%)$, which correspond to a density of 9,000 plants - ha-1 after 360 days. The litter singly contributed less to the survival than the forest soil, however a synergic effect between the two inputs was observed. The TBOTH presented a higher growth $(42 \mathrm{~cm}$ of plant height at 360 days). The costs of direct seeding with inputs (singly or combined) were higher than the conventional seedling planting in relation to the area unity. However, the cost of direct seeding without addition of inputs was higher considering the cost per survivor seedlings. Planted seedling of S. terebinthifolius reached 88.5 $\mathrm{cm}$ of height after 360 days. Seedlings of $S$. terebinthifolius generated by direct seeding reached the average of 5.1 and $42.0 \mathrm{~cm}$ of height in the TSEED and TBOTH treatments, respectively.
\end{abstract}

Keywords: Forest restoration; Soil transposition; Financial costs of restoration.

\section{AVALIAÇÃO DA SEMEADURA DIRETA DE DUAS ESPÉCIES DE ÁRVORES NEOTROPICAIS COM O USO DE INSUMOS NATURAIS}

\begin{abstract}
RESUMO - A semeadura direta de espécies arbóreas nativas pode ser uma alternativa de baixo custo para a restauração florestal. O trabalho teve como objetivo avaliar a semeadura direta de duas espécies do Sul do Brasil, Schinus terebinthifolius Raddi e Citharexylum solanaceum Chamisso, comparando com um plantio de mudas. Os efeitos e os custos da adição de solo florestal e serapilheira também foram avaliados na semeadura direta. O experimento foi realizado durante 2009/2010. Os tratamentos de semeadura direta foram CONTROL - controle sem semeadura, TSEED - somente semeadura, TLITTER - semeadura com serapilheira, TTOPSOIL - semeadura com solo florestal, TBOTH - semeadura com serapilheira e com solo florestal, LTCONTROL - controle com serapilheira e solo florestal. A espécie C. solanaceum não germinou no campo. A espécie S. terebinthifolius apresentou maior germinação na TBOTH com 30 dias $(21,6 \%)$ e 360 dias $(9,0 \%)$, correspondendo a uma densidade de 9.000 plantas/ha aos 360 dias. A semeadura com serapilheira isoladamente contribuiu menos para a sobrevivência do que o soloflorestal, no entanto, um efeito sinérgico entre os dois tratamentos foi observado. O TBOTH proporcionou maior crescimento (42 cm de altura em 360 dias). Os custos da semeadura direta com insumos (isoladamente ou combinado) foram maiores do que o plantio de mudas convencional por unidade de área. Entretanto, o custo por muda sobrevivente foi maior na semeadura direta sem insumos.
\end{abstract}




\begin{abstract}
Mudas plantadas de S. terebinthifolius atingiram $88,5 \mathrm{~cm}$ de altura após 360 dias. Plântulas de S. terebinthifolius geradas a partir da semeadura direta atingiram a média de 5,1 e 42,0 cm para nos tratamentos de semeadura direta TSEED e TBOTH, respectivamente.
\end{abstract}

Palavras-chave: Restauração florestal; Transposição do solo; Custos financeiros de restauração.

\section{INTRODUCTION}

The Atlantic Forest displays one of the greatest biodiversity and endemism reserves per unity area of the planet. The forest formations that belong to the Atlantic Forest were $15 \%$ of the Brazilian territory (Morellato and Haddad, 2000) and are nowadays reduced to near $7 \%$ of the original area (Myers et al., 2000). One third part of the remnant Atlantic Forest is in small forest fragments with less than 100 ha (Ribeiro et al., 2009). On the other hand, forest reduction still presents a great dimension. Brazil has been losing 2.9 million ha of forest per year and the net increment of planted forest (including commercial forestry) does not reach the 25 thousands ha per year (Brockerhoff et al., 2008).

The restoration of degraded forests needs multiple human interventions and the utilization of adequate methods. To such interventions, a deeper understanding of the effectiveness of alternative methods to planting of seedlings is needed. These alternatives are based on knowledge of silviculture of the species and selfregeneration of the forest communities, with the consequent reduction of costs (Ferreira et al., 2003; Hüller et al., 2009).

Seedling planting with species of different successional groups is the most frequent method in forest recovering (Kageyama et al., 1989; Knowles and Parrotta, 1995; Shono et al., 2007). As the economic return of native tree plantings is usually low and their costs are relatively high, "restoration plantings are probably an option that can only be used in a relatively small number of situations" (Lamb et al., 2005). Meanwhile, alternatives such as direct seeding or spontaneous regeneration trough secondary succession are promising to turn feasible the ecological and socio-economic dimensions of forest restoration (Engel and Parrotta, 2001; Reis et al., 2003).

Direct seeding tends to be an inexpensive method if compared to the seedling planting, requiring less equipment to the planting and greenhouse structure, allowing restoring wide areas with easy procedures (Araki, 2005). However, high quality seeds in sufficient abundance are frequently unavailable (Mattei, 1993) and their response at field is unpredictable (Engel and Parrotta, 2001).

The success of direct seeding is also dependent on favorable conditions for rapid germination. Unlike the condition on the nursery, the lethal agents of the field conditions are not under control (Mattei and Rosenthal, 2002; Woods and Elliot, 2004). Therefore, auxiliary procedures also must be tested, for instance straw and forest litter addition, physical protectors, organic manure supply and weed management.

Inputs such as mulching (Stevenson and Smale, 2005 ) or forest soil have been evaluated (Requena et al., 2001). On the other hand, these additions could increase the costs of direct seeding and, in spite of bringing benefits; they could hinder economically the activity. The measurement of costs for implementation of different cultivation systems is indispensable to plan restoration.

The present investigation of direct seeding has included two native tree species from Southern Brazil, Schinus terebinthifolius Raddi and Citharexylum solanaceum Chamisso. The first is a pioneer tree species frequently found in riparian habitats but also in dry land. It has small seeds, with near 26,000 seeds $\cdot \mathrm{kg}^{-1}$ (Lorenzi, 1992). The second species is a pioneer and hygrophilous tree species, occurring rather in riparian forests. The species has near 19,000 seed $\cdot \mathrm{kg}^{-1}$ (Lorenzi, 1992). The study was conducted in order to compare the germination and growth potential of seeds of the two species at field using different treatments of direct seeding. The costs, survival and growth data were compared with results of seedling planting, in the same field conditions.

As underlying hypotheses, we have tested if: 1 . direct seeding had lower costs than seedling plantation, 2 . addition of forest soil and litter could benefit the direct seeding and 3 . additional costs of the additives justify their application. 


\section{MATERIALAND METHODS}

\subsection{Study area}

The experiment was located at Conceição River margins in the Coronel Barros municipality, State of Rio Grande do Sul, Brazil (28²2’ 05,18" S; 54 32’ 09,89" W). The predominant soil class was Oxisol (USDA, 1999). The site was a crop area abandoned for 20 years, because it is part of permanent preservation area according to the Brazilian laws. Until the experiment the area has been used to crop cultivation (maize, wheat, soybeans). Some individuals of ligneous species, e. g. Solanum mauritianum Scop. and Ateleia glazioveana Baill., were observed during the evaluation.

The physic-chemical soil profile (Table 1) was provided by the Soil Laboratory of UNIJUÍ University (Ijuí-RS, Brazil).

The typical vegetation in the region is the Seasonal Semideciduous Forest. The climate is humid subtropical Cfa, according Köppen System (Moreno, 1961). The annual average temperature is $21.8^{\circ} \mathrm{C}$ and the annual rainfall is $1,735 \mathrm{~mm}$ (Instituto Regional de Desenvolvimento Rural/UNIJUÍ, Augusto Pestana, Brazil). During the experiment, the highest mean maximal temperature was $34.5^{\circ} \mathrm{C}$ (December 2009) and water stress conditions were observed only to March 2010 (Table 2).

The direct seeding has included seeds of $S$. terebinthifolius and C. solanaceum. For the second species, scarified seeds have also been evaluated. The seeds were submitted to scarification in a mechanical device equipped with a cylinder covered by sandpaper during 20 minutes under 1,200 rpm, following the indications of Zemetra et al. (1983). For both species potential germination was tested in laboratory and also in a nursery.

The experiment was established during September 2009 , in a randomized design with six replications for each the six treatments and for each species.

The treatments were (Control) - control without seeding, (TSeed) - only seeding, (TLitter)- seeding with forest litter cover,(TTopsoil) - seeding with forest topsoil, (TBoth) - seeding with forest litter and with forest topsoil, (LTControl) - control with forest litter and forest topsoil.

The seeds were covered with 2-4 mm of soil in all treatments. The area was prepared through mechanical plowing.
Each plot of $2 \times 2.5 \mathrm{~m}$ received 50 seeds, corresponding to $100,000 \mathrm{seeds} / \mathrm{ha}$. The plots with litter addition were covered uniformly with $9.0 \mathrm{~kg}$ (fresh weight) of forest litter material, corresponding to $18,000 \mathrm{~kg} / \mathrm{ha}$. The forest soil was obtained from $0-20 \mathrm{~cm}$ deep and was added in the amount of $18 \mathrm{~kg}$ (fresh weight) per plot, corresponding to $36,000 \mathrm{~kg} / \mathrm{ha}$. The physic-chemical profile of the soil and the litter was determined (Table 1).

To comparison purposes the initial development and costs of seedling planting was carried out in the same site. The seedlings were produced in conical polypropylene tubes in a nursery. They are brought to the planting site with $20-30 \mathrm{~cm}$ of height with near three months age. The planting pits were $30 \times 30 \times 30$ $\mathrm{cm}$ and were open manually $2 \times 2$ spaced, without any kind of fertilizers. Three hundred seedlings of each species were divided in 12 replications of 25 seedlings each.

The cultural operations have included the cut-ant and weed control. The weed control was performed six months after planting and seedling with the aid of a mechanical mowing.

The evaluation of costs was carried out through measurement of all operations costs and they are hectare based. In the manual operations, the values were calculated based on man/days costs, and for the mechanized operations the costs were calculated as hours/machine operation, according to the values usually practiced in the region. The valuation of the forest litter and forest soil was based on the values of workforce needed to gathering, transport and application.

\subsection{Measurements and statistics}

The survival has been measured with reference to the initial number of seeds. The costs were calculated in Reais (R\$) and transformed in US dollars (U\$ \$) considering the proportion of $\mathrm{R} \$ 1.60 / \mathrm{U} \$ \$ 1.00$ which was the current value in the end of the experiment (September 2010).

The germination data were submitted to a oneway ANOVA after data transformation according to, $p^{\prime}=\operatorname{arcsen} \sqrt{p}$ where $p$ is the proportion of germinated seeds. The pair wise analysis was carried out trough Duncan test $(P<0.05)$. The statistic analysis was executed with software SASM-Agri (Canteri et al., 2001) and WinSat (Machado and Conceição, 2003).

Revista Árvore. 2017;41(4):e410405

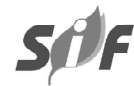


Table 1 - Physic-chemical of the soil in the experimental area, in the forest soil and the litter.

Tabela 1 - Físico-química do solo na área experimental, no solo florestal e na serapilheira.

\begin{tabular}{|c|c|c|c|c|}
\hline & \multicolumn{2}{|c|}{ Soil in the experimental area } & \multirow[t]{2}{*}{ Forest soil } & \multirow[t]{2}{*}{ Litter } \\
\hline & $0-15 \mathrm{~cm}$ & $15-30 \mathrm{~cm}$ & & \\
\hline $\mathrm{pH}$ & 4.7 & 4.6 & 5.0 & ND \\
\hline Actual CEC - $\left(\mathrm{Cmol}_{\mathrm{c}} / \mathrm{dm}^{3}\right)$ & 10.3 & 9.5 & 15.4 & ND \\
\hline $\mathrm{CEC}$ at $\mathrm{pH} 7-\left(\mathrm{Cmol}_{\mathrm{c}} / \mathrm{dm}^{3}\right)$ & 21.9 & 20.5 & 19.9 & ND \\
\hline $\mathrm{C}-\mathrm{mg} / \mathrm{dm}^{3}$ & ND & ND & ND & 454.1 \\
\hline $\mathrm{N}-\mathrm{mg} / \mathrm{dm}^{3}$ & ND & ND & ND & 2.16 \\
\hline $\mathrm{P}-\mathrm{mg} / \mathrm{dm}^{3}$ & 4.2 & $<3.0$ & 7.7 & 0.94 \\
\hline $\mathrm{K}-\mathrm{mg} / \mathrm{dm}^{3}$ & 93 & 44 & 312 & 2.53 \\
\hline $\mathrm{Al}-\left(\mathrm{cmol}_{\mathrm{c}} / \mathrm{dm}^{3}\right)$ & 0.7 & 1.3 & 0.2 & ND \\
\hline $\mathrm{Ca}-\left(\mathrm{cmol}_{\mathrm{c}} / \mathrm{dm}^{3}\right)$ & 7.2 & 6.6 & 10.8 & 42.4 \\
\hline $\mathrm{Mg}-\left(\mathrm{cmol}_{\mathrm{c}} / \mathrm{dm}^{3}\right)$ & 2.2 & 1.5 & 3.6 & 1.28 \\
\hline $\mathrm{OM}(\%) \mathrm{m} / \mathrm{v}$ & 3.4 & 3.0 & 4.4 & ND \\
\hline
\end{tabular}

$\mathrm{ND}=$ not determined.

Table 2 - Weather conditions during the experiment (September 2009 to September 2010).

Tabela 2 - Condições climáticas durante o experimento (setembro de 2009 a setembro de 2010).

\begin{tabular}{lccc}
\hline & & & \multicolumn{2}{c}{ Temperature } \\
\hline month & Rainfall $(\mathrm{mm})$ & Mean Minimum $\left({ }^{\circ} \mathrm{C}\right)$ & Mean Maximum $\left({ }^{\circ} \mathrm{C}\right)$ \\
\hline October 2009 & 348.0 & 9.8 & 21.9 \\
November 2009 & 126.9 & 11.7 & 26.7 \\
December 2009 & 471.5 & 18.2 & 32.9 \\
January 2010 & 217.9 & 20.9 & 34.5 \\
February 2010 & 262.9 & 18.2 & 30.4 \\
March 2010 & 277.7 & 16.9 & 28.4 \\
April 2010 & 72.0 & 15.7 & 27.7 \\
May 2010 & 179.2 & 11.7 & 23.0 \\
June 2010 & 149.7 & 8.0 & 13.8 \\
July 2010 & 119.8 & 8.5 & 14.7 \\
August 2010 & 225.3 & 7.2 & 16.9 \\
September 2010 & 12.8 & 10.9 & 22.3 \\
\hline
\end{tabular}

Source: IRDeR/UNIJUÍ-RS.

\section{RESULTS}

The germination of $S$. terebinthifolius was higher than of C. solanaceum in laboratory with $47.6 \%$ and $5.6 \%$, respectively $(P<0.05$, Duncan test $)$. In the nursery, again germination of $S$. terebinthifolius was superior than of C. solanaceum, with $47.6 \%$ and $10.0 \%$, respectively ( $P<0.05$, Duncan test). Scarification of $C$. solanaceum seeds increased significantly the germination only in the nursery, to $43.2 \%$.

The species $C$. solanaceum did not germinate in any field conditions. For $S$. terebinthifolius the higher emergence was observed in TTOPSOIL and TBOTH at 30 days (21.3 and $21.6 \%$ ). TBOTH remained the treatment with highest survival until the final evaluation at 360 days (Fig. 1).
The results of growth also point towards a superiority of the TBOTH, reaching $42 \mathrm{~cm}$ of height at 360 days (Table 3).

Among the direct seeding treatments the financial costs were positively correlated with the survival and growth values. On the other hand, the cost per survivor seedling after 360 days presented an inverse correlation with the costs (Table 4). The planted seedlings of S. terebinthifolius and C. solanaceum had 83.3 and 92.0 of survival after 360 days, and the average height was $88.5 \mathrm{~cm}$ and $77.5 \mathrm{~cm}$, respectively.

The implementation and maintenance during the first year for direct seeding are more costly than for seedling planting, except thetreatmentwithoutadditives(TSEED). Thetreatments TTOPSOIL and TBOTH exhibited higher values of survival and growth and, concomitantly, the greater costs per unit area. 


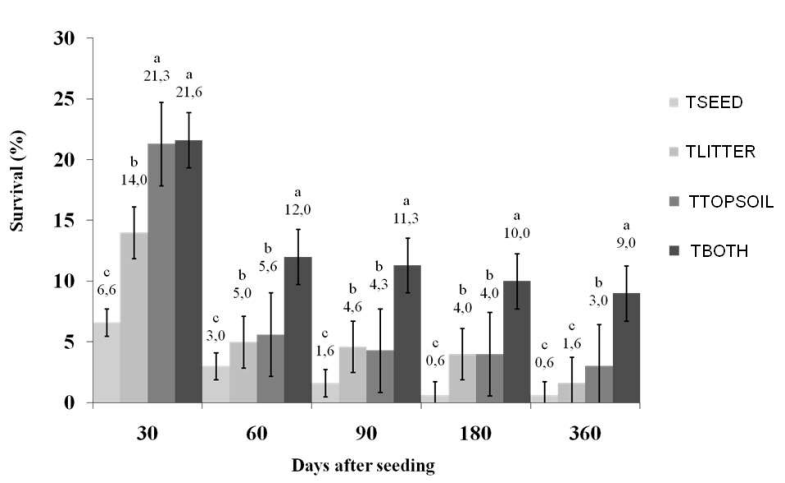

Figure 1 -(TSeed) - only seeding, (TLitter)- seeding with forest litter cover,(TTopsoil) - seeding with forest topsoil, (TBoth) - seeding with forest litter and with forest topsoil

Figura 1 - (TSeed) - somente sementes, (TLitter)- semeadura com adição de serapilheira,(TTopsoil) - semeadura com adição de solo superficial, (TBoth) - semeadura com adição de serapilheira e solo superficial

\section{DISCUSSION}

The survival of S. terebinthifolius at the first 30 days was higher in the treatments with addition of forest soil (TTOPSOIL) and addition of both forest litter and forest soil. It suggests that the added soil has a superior contribution in the early development than the forest litter, possibly representing a source of more soluble nutrients. From 90 days, the concomitant addition of litter and soil exhibited higher values of survival and the effect of soil addition singly had a gradual reduction. The concomitant addition of litter and forest soil presented a synergic effect to the survival, since the sum of the effects of these additives was lower than the benefit of the joint application. On the other hand, after 360 days the application of litter did not have significant differences in relation to the control, which does not justify their use singly.

Both forest litter and forest soil had physic-chemical features which potentially could facilitate the early growth of the seedlings. Forest soil presented high levels of $\mathrm{Ca}, \mathrm{K}$, and organic matter. On the other hand, the clay content was only $35 \%$, reducing the possibility of soil compaction by the rain. Meanwhile, the litter had high level of $\mathrm{C}, \mathrm{N}$ and $\mathrm{Ca}$. Data suggest that the litter addition could contribute to the survival if accompanied by a nutrient supply, in this case represented by the forest soil. On the other hand, addition of dead plant material to the soil increases the microbial activities and therefore the nitrogen consumption (Smettem et al., 1992), which requires compensation.

The survival of seedlings had an early critical period in the first 60 days after the seeding, during which the majority of the seedling losses have occurred. During such period, moisture and protection could be decisive (Ferreira et al., 2009). Nevertheless, the addition of forest litter which should promoted physical protection (Woods and Elliott, 2004) did have minor effects when compared to the addition of soil. Other studies have pointed out the ineffectiveness of litter addition (Stevenson and Smale, 2005).

Eighty two percent of the seedling losses have been observed between 30 and 360 days occurred until 90 days. As a general rule the survivorship of plants presents greatest levels of mortality in the beginning of the life cycle, decreasing gradually (Silvertown, 1987). Any techniques able to reduce the deaths in this early period could contribute significantly to optimize the direct seeding of the species.

For the height, again TBOTH had the higher values among the treatments. The height results of forest soil and forest litter singly was similar, and the sum of the two approximates to the value of TBOTH, delineating an additive effect.

The forest soil theoretically could have promoted emergence of other forest tree species from the seed bank (Reis et al., 2003; Braga et al., 2007). However, no other woody species have emerged through soil transposition in any treatments, which could have been caused by an unfavorable period of the year for the harvest of the soil, and further investigations are needed to validate the soil transposition as an effective method in that ecoregion.

The higher costs of TTOPSOIL and TBOTH treatments are especially due to the litter and forest soil operations. In the TBOTH (the more expensive) the litter addition represented $31 \%$ and the forest soil $33 \%$ of costs. Both have reached almost $2 / 3$ of the total costs. The seed purchasing and soil preparation was only $10 \%$ and $3 \%$ of costs, respectively. The operations of seeding and input addition amounted to $10 \%$, and the maintenance operations were $14 \%$ of total costs. If the only contribution of the inputs is nutrient addition, 
Table 3 - Average height $\mathrm{cm}$ of seedlings of $S$. terebinthifolius as a function of time.

Tabela 3 - Altura média de plântulas de S. terebinthifolius como uma função do tempo.

\begin{tabular}{lcccccc}
\hline & \multicolumn{5}{c}{ Treatments } \\
\cline { 2 - 6 } & CONTROL & TSEED & TLITTER & TTOPSOIL & TBOTH & CONTROL \\
\hline 60 days & 0 & $2.4 \mathrm{~b}$ & $2.6 \mathrm{~b}$ & $2.8 \mathrm{~b}$ & $4.1 \mathrm{a}$ & 0 \\
90 days & 0 & $2.4 \mathrm{c}$ & $4.4 \mathrm{~b}$ & $4.0 \mathrm{bc}$ & $0.6 \mathrm{a}$ & 0 \\
180 days & 0 & $3.9 \mathrm{c}$ & $15.4 \mathrm{~b}$ & $16.7 \mathrm{~b}$ & $24.7 \mathrm{a}$ & 0 \\
360 days & 0 & $5.07 \mathrm{c}$ & $18.4 \mathrm{bc}$ & $21.7 \mathrm{~b}$ & 0 \\
\hline
\end{tabular}

letters indicate differences in the Duncan test $(P<5 \%)$

Table 4 - Costs (U\$ $\$ /$ ha) for each operation in direct seeding (CONTROL-TBOTH) and seedling planting (SP).

Tabela 4 - Custos (U\$\$/ha) para cada operação em semeadura direta (CONTROL-TBOTH) e plantio de mudas (SP).

\begin{tabular}{|c|c|c|c|c|c|c|}
\hline & CONTROL & TSEED & TLITTER & TTOPSOIL & TBOTH & $\mathrm{SP}$ \\
\hline Seedlings & - & - & - & - & - & 859.37 \\
\hline Seeds & - & 360.00 & 360.00 & 360.00 & 360.00 & - \\
\hline Soil preparation * & 127.31 & 127.31 & 127.31 & 127.31 & 127.31 & 257.80 \\
\hline Workforce to seeding and planting $* *$ & - & 159.12 & 159.12 & 159.12 & 159.12 & 214.84 \\
\hline Litter gathering $* *$ & - & - & $1,125.00$ & - & $1,125.00$ & - \\
\hline Forest soil gathering $* *$ & - & - & - & $1,200.00$ & $1,200.00$ & - \\
\hline Weed control around seedlings $* *$ & - & 254.62 & 254.62 & 254.62 & 254.62 & 343.75 \\
\hline Ant control & 57.28 & 57.28 & 57.28 & 57.28 & 57.28 & 91.66 \\
\hline Formicide & 55.55 & 55.55 & 55.55 & 55.55 & 55.55 & 80.00 \\
\hline Litter and Forest soil application $* *$ & - & - & 190.96 & 190.96 & 190.96 & - \\
\hline $\begin{array}{l}\text { Mowing ** } \\
\text { Results }\end{array}$ & - & 127.33 & 127.33 & 127.33 & 127.33 & 114.58 \\
\hline Total costs & 240.15 & $1,141.23$ & $2,457.20$ & $2,532.20$ & $3,657.20$ & $1,897.64$ \\
\hline Density (seedlings/ha) after one year & & 600 & 1,600 & $\mathbf{3 , 0 0 0}$ & $\mathbf{9 , 0 0 0}$ & 2,108 \\
\hline Cost of survival seedling & - & 1.90 & 1.54 & $\mathbf{0 . 8 4}$ & $\mathbf{0 . 4 1}$ & $\mathbf{0 . 9 0}$ \\
\hline
\end{tabular}

Mechanical work $=$ values calculated in hour/machine $(\mathrm{HM})$.

Manual workforce $=$ values calculated in $\mathrm{man} /$ day $(\mathrm{HD})$.

other less expensive sources of nutrients must be tested. However, forest soil could be a source of mycorrhizae (Requena et al., 2001), and such biological effect needs further investigation.

In spite of the higher costs, TTOPSOIL and TBOTH exhibited the higher density of seedling, which was higher than the seedling planting. On the other hand, the cost per seedling was the lowest to the TBOTH. Considering that the densities of seedling in the treatments TTOPSOIL and TBOTH were excessive (3,000 and 9,000/ha, respectively), a reduction of inputs could produce a reduction of costs, optimizing the use of additives.

Engel and Parrotta (2001) had observed implantation values (including maintenance in the first two years) between US\$1,054 and 1,287 (updated values to 2011 according to the Consumer Price Index), where the major costs were seeds acquisition (U\$ \$ 257) and workforce for the seeding operation (U\$\$ 165 to 231). The costs reported by these authors are similar to the costs of
TSEED treatment. However, the costs reported by Engel and Parrotta (2001) refer to the two first years and the seedling density obtained was not informed, making difficult the comparison.

The number of seedlings produced from the total seeds ranged between $0.6 \%$ (TSEED) and $9.0 \%$ (TBOTH). As a general rule, less than $10 \%$ of the seeds of tree species produce seedlings in direct seeding after one year except for species with big seeds $(>1.0 \mathrm{~g}$ ) (Camargo et al., 2002; Araki, 2005; Escaio et al., 2012). To Enterolobium contortisiliquum, Engel and Parrotta (2001) reported $18 \%$ of seeds that resulted in seedlings after two years, which could be considered an exceptional outcome. In spite the low rates of early survival, the direct seeding of $S$. terebinthifolius could be used as a method of enrichment in degraded areas where the spontaneous regeneration is in initial phase and a faster colonization would be not decisive for inhibit growth of weeds. 


\section{CONCLUSIONS}

The direct seeding could be considered viable for $S$. terebinthifolius but not for $C$. solanaceum without further studies on the germination viability of the second species.

The forest soil could be used as an additive with forest litter instead of singly; further studies could investigate the optimal amount of inputs to minimize the costs.

The costs of each survivor seedling of $S$. terebinthifolius were higher for the direct seeding without inputs and were reduced by the inputs addition.

\section{ACKNOWLEDGEMENTS}

To Andressa Felipin for the English review.

\section{REFERENCES}

Araki DF. Avaliação da semeadura a lanço de espécies florestais nativas para recuperação de áreas degradadas [dissertação]. Piracicaba: Escola Superior de Agricultura Luiz de Queiroz; 2005.

Braga AJT, Griffith JJ, Paiva HD, Silva FD, Corte VB, Meira Neto JAA. Enriquecimento do sistema solo-serapilheira com espécies arbóreas aptas para recuperação de áreas degradadas. Revista Árvore. 2007;31:1145-54.

Brockerhoff EG et al. Plantation forests and biodiversity: oxymoron or opportunity? Biodiversity Conservation. 2008; 17:925-51.

Camargo JLC, Ferraz IDK, Imakawa AM. Rehabilitation of degraded areas of Central Amazonia using direct sowing of forest tree seeds. Restoration Ecology 2002;10:636-44.

Canteri MG, Althaus RA, Virgens Filho JS, Giglioti EA, Godoy CV. SASM - Agri: Sistema para análise e separação de médias em experimentos agrícolas pelos métodos Scoft-Knott, Tukey e Duncan. Revista Brasileira Agrocomputação. 2001;1:18-24

Engel VL, Parrotta JA. An evaluation of direct seeding for reforestation of degraded lands in central São Paulo state, Brazil. Forest Ecology Management. 2001;152:169-81.
Escaio AC et al. Emergence and growth of Ateleia glazioveana Baill. seedlings in direct sowing in an early secondary succession stage. Brazilian Journal of Ecology. 2012;1:33-9.

Ferreira RA, Davide AC, Motta MS. Restauração florestal: estudo da regeneração natural em área implantada por meio de semeadura direta. In: Anais do $5^{\circ}$ Simpósio Nacional Sobre Recuperação de Áreas Degradadas. Curitiba: SOBRADE, 2003. p.475-7.

Ferreira RA, Santos PL, Aragão AG, Santos TIS, Santos Neto EM, Rezende MAS. Semeadura direta com espécies florestais na implantação de mata ciliar no Baixo São Francisco em Sergipe. Scientia Forestalis. 2009;37:37-46.

Hüller A, Coelho GC, Lucchese AO, Schirmer JA. Comparative study of four tree species used in riparian forest restoration along Uruguay River, Brazil. Revista Árvore. 2009;33:297-304.

Kageyama PY, Castro CFA, Carpanezzi AA. Implantação de matas ciliares: estratégia para auxiliar a sucessão secundária. In: Barbosa LM, editor. Simpósio Sobre Mata Ciliar. Campinas: Fundação Cargill; 1989. p.130-43.

Knowles OH, Parrotta JA. Amazonian forest restoration: an innovative system for native species selection based on phenological data and field performance indices. The Commonwealth Forestry Review. 1995;74:230-43.

Lamb D, Erskine PD, Parrotta JA. Restoration of degraded tropical forest landscapes. Science. 2005;310(5754):1628-32.

Lorenzi H. Árvores brasileiras: manual de identificação e cultivo de plantas arbóreas nativas do Brasil. Nova Odessa: Plantarum; 1992. 360p.

Machado AA, Conceição AR. WinStat: sistema de análise estatística para Windows. Versão 2.0. Pelotas: Universidade Federal de Pelotas; 2003.

Mattei VL. Comparação entre semeadura direta e plantio de mudas produzidas em tubetes, na implantação de povoamentos de Pinus taeda $\mathrm{L}$ [tese]. Curitiba: Universidade Federal do Paraná; 1993.

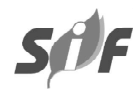


Mattei VL, Rosenthal MD. Semeadura direta de canafístula (Peltophorum dubium (Spreng.) Taub.) no enriquecimento de capoeiras. Revista Árvore. 2002;26:649-54.

Morellato LPC, Haddad CFB. Introduction: the Brazilian Atlantic Forest. Biotropica. 2000;32:786-92.

Moreno JA. Clima do Rio Grande do Sul. Porto Alegre: Secretaria da Agricultura do Rio Grande do Sul; 1961.

Myers N et al. Biodiversity hotsposts for conservation priorities. Nature. 2000;403(6772):853-8.

Reis A, Bechara FC, Espíndola MB, Vieira NK, Souza LL. Restoration of damaged land areas: using nucleation to improve successional processes. Natureza \& Conservação. 2003;1:85-92.

Requena N, Perez-Solis E, Azcón-Aguilar C, Peter Jeffries P, Barea JB. Management of indigenous plant-microbe symbioses aids restoration of desertified ecosystems. Applied and Environmental Microbiology. 2001;67:495-8

Ribeiro MC, Metzger JP, Martensen AC, Ponzoni FJ, Hirota MM. Brazilian Atlantic forest: how much is left and how is the remaining forest distributed? Implications for conservation. Biological Conservation. 2009;142:1141-53.

Shono K, Davies SJ, Chua YK. Performance of 45 native tree species on degraded lands in
Singapore. Journal of Tropical Forest Science. 2007;19:25-34.

Silvertown JW. Introduction to plant ecology. $2^{\text {nd }}$ ed. Essex: Longman Scientific and Technical; 1987. 229p.

Smettem KRJ, Rovira AD, Wace SA, Wilson BR, Simon A. Effect of tillage and crop rotation on the surface stability and chemical properties of a redbrown earth (Alfisol) under. Soil \& Tillage Research. 1992;22:27-40.

Stevenson BA, Smale MC. Seed bed treatment effects on vegetation and seedling establishment in a New Zealand pasture one year after seeding with native woody species. Ecological Management \& Restoration. 2005;6:124-31.

United States Departament of Agriculture - USDA. Soil taxonomy - a basic system of soil classification for making and interpreting soil surveys. $2^{\text {nd }}$. ed. Washington: $1999.871 \mathrm{p}$.

Woods K, Elliott S. Direct seeding for Forest restoration on abandoned agricultural land in Northern Thailand. Journal of Tropical Forest Science. 2004;16:248-59.

Zemetra RS, Havstad C, Cuany RL. Reducing seed dormancy in Indian Ricegrass (Oryzopsis hymenoides). Journal of Range Management. 1983;36:239-41. 